\title{
A Perspective on Future Tiger Shark Research
}

\author{
Kim N. Holland ${ }^{1 *}$, James M. Anderson ${ }^{1}$, Daniel M. Coffey ${ }^{1}$, Bonnie J. Holmes², \\ Carl G. Meyer ${ }^{1}$ and Mark A. Royer ${ }^{1}$ \\ ${ }^{1}$ Hawaii Institute of Marine Biology, University of Hawaii at Manoa, Kaneohe, HI, United States, ${ }^{2}$ Department of Agriculture
and Fisheries, Brisbane, QLD, Australia
}

This "Perspectives" paper identifies aspects of tiger shark (Galeocerdo cuvier) biology that are currently unknown or for which additional data are needed to improve interpretive power. Some of these data gaps may be regional. Technical or methodological approaches to acquiring these data are suggested. Some of these technologies already exist, some are in development and some exist in concept only. Reproductive biology and behavior, social interactions and the behavioral ecology of sub-adults are among the areas identified as deserving of future research effort.

Keywords: tiger sharks, behavior, research perspectives, tracking, ecology, population connectivity

\section{OPEN ACCESS INTRODUCTION}

Edited by: Tiger sharks (Galeocerdo cuvier) are large, iconic predators with a circumglobal distribution in Mark Meekan, Australian Institute of Marine Science (AIMS), Australia

Reviewed by:

Colin Simpfendorfer, James Cook University, Australia Neil Hammerschlag,

University of Miami, United States

*Correspondence:

Kim N. Holland

kholland@hawaii.edu

Specialty section

This article was submitted to

Marine Megafauna,

a section of the journal

Frontiers in Marine Science

Received: 28 June 2018

Accepted: 23 January 2019

Published: 14 February 2019

Citation:

Holland KN, Anderson JM,

Coffey DM, Holmes BJ, Meyer CG and Royer MA (2019) A Perspective

on Future Tiger Shark Research.

Front. Mar. Sci. 6:37.

doi: 10.3389/fmars.2019.00037 warm waters (Compagno, 1984). They play an important role in ecosystem function (Heithaus and Dill, 2002; Ferreira et al., 2017; inter alia) and are among the top three shark species identified in attacks on humans (International Shark Attack File ${ }^{1}$ ). This paper identifies several aspects of tiger shark biology that are currently unknown or poorly understood and which we believe are critical to our understanding of this important predator. These data gaps may vary regionally. We focus on questions that are specific to tiger sharks and which are amenable to manipulative or empirical field experiments (as opposed to correlative analyses) There may be other fruitful areas for investigation that are not covered here. Tools for investigating the biology of vagile marine species are constantly and rapidly improving. These include increasingly sophisticated molecular techniques, portable analysis units (e.g., ultrasonic scanners) and multi-sensor electronic tags for tracking three-dimensional movements and sampling the environment surrounding the focal animal. We suggest technical solutions or methodological approaches for acquiring data to fill gaps in our knowledge of tiger shark biology. Some of these technologies already exist, some are in development and others currently exist in concept only.

\section{REPRODUCTIVE BIOLOGY AND BEHAVIOR}

\section{Topic: Pupping, Mating and Gestation Locations}

Tiger sharks have low reproductive output (Simpfendorfer, 1992; Whitney and Crow, 2007) making survival of juveniles (and protection of nursery areas) potentially critical to conservation strategies. Although many shark species utilize specific locations (e.g., coastal embayments or estuaries) as

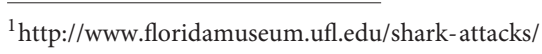


nursery areas (as defined by Heupel et al., 2007), tiger sharks apparently lack well-defined nursery areas (Springer, 1967; Whitney and Crow, 2007; Driggers et al., 2008). For example, catch per unit effort (CPUE) surveys show tiger shark pups and juveniles are widely distributed at depths $<100 \mathrm{~m}$ along the continental shelf of the southeastern United States with highest CPUE near the "Charleston Bump" (Driggers et al., 2008). It is not known whether this broad distribution of pups results from widespread pupping by adult females or dispersal of pups from more specific parturition sites or an extended pupping season (Driggers et al., 2008). The partial migration of adult females from remote Hawaiian atolls to the main Hawaiian Islands during pupping season (Papastamatiou et al., 2013) suggests that there may be preferred tiger shark pupping habitats in Hawaii but this has not been confirmed. Similarly, if specific pupping sites do exist, it is not known if adult female sharks show repeated fidelity to those sites. Sulikowski et al. (2016) speculate there may be specific gestation grounds in the Bahamas but the wide ranging movements of pregnant sharks in other regions (e.g., Papastamatiou et al., 2013) indicate that, if such behavior exists, it may be regionally specific.

The seasonal timing of tiger shark mating is evident from mating scars on females (e.g., Whitney and Crow, 2007), but very little is known about the nature of mating behavior (see Meyer et al., 2018) or whether or not there are specific mating sites. Tiger sharks seem to be generally solitary, so finding a mate may be challenging unless there are specific locations and times when mating occurs. Within the main Hawaiian Islands, the probability of migration between islands for both adult male and female tiger sharks peaks during the winter mating season as does CPUE for adult males in shallow coastal habitats (Papastamatiou et al., 2013; Meyer et al., 2018; A. Tester unpublished data). These observations, in conjunction with a single observation of a failed mating attempt by a camera-equipped male tiger shark in coral reef habitat (Meyer et al., 2018), suggest shallow coastal areas are mating habitats for Hawaii tiger sharks. There are currently no similar data from other parts of the world.

\section{Future Research}

One strategy for addressing the nursery location/depth and gestation grounds questions would be to capture adult female tiger sharks during pupping season, scan them with portable ultrasound equipment to see if they are pregnant (Sulikowski et al., 2016) and, if so, equip these sharks with cameras and accelerometry tags to detect pupping events. These sharks could also be equipped with satellite tags to provide insight into where pupping is occurring. These experiments should be geographically widespread.

A longer-term approach would be development of implantable devices that can detect key aspects of blood chemistry that indicate parturition. These physiological data would be transmitted to an externally mounted pop-off tag which would transmit these data via satellite. This dual internal/external tag technology has been successfully used to detect feeding behavior in several marine species including seals (e.g., Skinner et al., 2014). Similarly, equipping mature males with camera and depth and light level sensor packages during mating season (e.g.,
Meyer et al., 2018) would be the most direct path to elucidating the location and nature of mating behavior.

\section{Topic: Reproductive Cycle}

The reproductive cycle of tiger sharks remains one of the least understood aspects of its reproductive biology. Initial work in this area suggested a biennial reproductive cycle (Rivera-López, 1970; Alves, 1977), and that mating appeared to occur before fullterm females had pupped (Branstetter et al., 1987). More recently, Castro (2009) surmised that North Atlantic tiger sharks probably have a gestation period of 12 months, based on the observation of tiger sharks carrying both unfertilized eggs and near-term young in May (boreal spring), indicating that females are possibly reproductively synchronous in this region. Conversely, Whitney and Crow (2007) inferred a triennial breeding cycle for Hawaiian tiger sharks, reporting that the proportion of captured sharks that were pregnant was lower than would be expected for a biennial reproductive cycle. The identification of potential differences in reproductive strategies between Atlantic and Indo-Pacific tiger sharks is critical to inform regional stock assessment and fishery management regimes.

\section{Future Research}

Geographically diverse data on the reproductive state of large numbers of mature females is required. To avoid lethal sampling, portable ultrasound equipment could be used to assess pregnancy and in-utero pup sizes. Blood chemistry could be sampled from live sharks to determine temporal changes in hormone levels to deduce reproductive cycle status (Sulikowski et al., 2016).

\section{Topic: Sex Separation and Habitat Partitioning}

Sexual segregation occurs among adults of many shark species (Meyer et al., 2009; Papastamatiou et al., 2010) and existing evidence suggests this phenomenon may also occur in tiger sharks (Meyer et al., 2014). Tiger shark sex ratio is reported to be close to 1:1 at birth in Hawaii (Whitney and Crow, 2007), while significantly biased toward females off eastern Australia (1.26:1, Holmes, 2015). Concomitantly catches of adults tend to be heavily female-skewed in most coastal locations (Simpfendorfer, 1992; Wintner and Dudley, 2000; Beerkircher et al., 2002; Meyer et al., 2014; inter alia). This is thought to result from adult females occupying coastal areas (where most fishing effort occurs), while adult males occupy more offshore habitats for most of the year (Papastamatiou et al., 2013). It is not known at what age this segregation occurs. Size-specific analyses of catch records off eastern Australia revealed catches of males on near-shore shark control gear declined when males reached $>280 \mathrm{~cm}$ TL (Holmes et al., 2012), potentially indicating greater offshore habitat selection with the onset of male sexual maturity $\left(L_{50}\right.$ males $=297 \mathrm{~cm}$ TL, Holmes, 2015).

\section{Future Research}

To distinguish gender-related habitat segregation from a population-wide disparity in sex ratio, simultaneous fishing should be conducted in inshore vs. offshore habitats at multiple 
locations around the world. Further size-specific analysis and movement data (e.g., Lea et al., 2018) might reveal the ontogeny of sexual segregation in other regions. Specifically targeting males for future tracking experiments would also elucidate differences in habitat selection.

\section{Topic: Occurrence and Frequency of Multiple Paternity}

Many carcharhinid species display multiple paternity which is a strategy to amplify the functional size and diversity of the reproductive population (Daly-Engel et al., 2006). A single study of tiger sharks (using a small sample size) did not detect multiple maternity (Holmes et al., 2018). Given its importance to conservation biology, multiple paternity should be more thoroughly investigated worldwide.

\section{Future Research}

Opportunistic tissue sampling of tiger shark pups from known mothers should be conducted on a world-wide scale. Coupled with portable ultrasound equipment, it may be possible to use a biopsy needle to non-lethally sample pups from pregnant females.

\section{POPULATION DYNAMICS AND CONNECTIVITY}

\section{Topic: Population Connectivity}

Whereas tiger shark populations seem to be distinct among the different oceans, there is still debate about within-ocean population structure and there appears to be a discrepancy between the within-basin population structure indicated by molecular genetics and the large-scale movements of tagged individuals in both the Atlantic and Indo-Pacific Oceans (Holmes et al., 2014; Werry et al., 2014; Lea et al., 2015). A recent analysis using nuclear markers (microsatellites) indicated broad genetic differentiation between the Atlantic and the Indo-Pacific Ocean basins with considerable regional structure within the Atlantic and some structure within the Pacific - including a separate Hawaiian population (Bernard et al., 2016). However, this distinction was not observed in a study using a larger sample size (Holmes et al., 2017). Apparently, roaming individuals provide enough gene flow to maintain large, basin-wide populations. These different results indicate that further connectivity research is warranted globally.

\section{Future Research}

Development of single nucleotide polymorphisms (SNP) for tiger sharks would complement microsatellite techniques and increase the power to detect genetic variation and metapopulations, even if sample sizes are small. Continued advances in tagging technology that allow for multi-year tracks of mature sharks (e.g., Lea et al., 2015), coupled with the advancement of molecular analyses, is likely to greatly improve our understanding of sexbiased dispersal, reproductive mixing and other spatiotemporal movement drivers that influence population structure and connectivity. Climate change should see a range extension through pole-ward movements in this species, which may increase the potential for greater trans-oceanic movements.

\section{BEHAVIORAL ECOLOGY}

\section{Topic: Behavioral Ecology of Pups}

Virtually nothing is known about the behavior and habitat use of tiger shark pups during their first years of life including how quickly they disperse from their natal sites, what depths or types of habitat they select or how this changes with ontogeny. We do not know how early feeding experience impacts the feeding strategies of sharks later in their lives.

\section{Future Research}

Active acoustic tracking (e.g., Holland et al., 1993) and passive acoustic monitoring using anchored receiver arrays (e.g., Heupel and Hueter, 2001) would greatly improve understanding of the behavior of neonate and juvenile tiger sharks. Young-of-theyear and juvenile tiger sharks are of sufficient body size to carry temperature-depth recorders and accelerometers to better understand three-dimensional spatial use and activity rates. Diet could be estimated using non-lethal techniques including gastric lavage (Bangley et al., 2013) and stable isotope analyses (Kinney et al., 2011). Respirometry experiments and feeding studies with captive juveniles would elucidate daily ration and energetics requirements (Lowe, 2002).

\section{Topic: Offshore Movements of Adults}

Satellite telemetry (Lea et al., 2015; Meyer et al., 2018) and catch records (Polovina and Lau, 1993; Domingo et al., 2016) show tiger sharks make offshore migrations in both the Pacific and Atlantic. Adult tiger sharks in the Atlantic undertake repeated annual migrations which track latitudinal shifts in sea surface temperatures (SST) (Lea et al., 2015, 2018). Hammerschlag et al. (2012) correlated oceanic tiger shark movements in the midAtlantic with catch rates of pelagic fishes, although the causation is unknown. Intriguingly, some sharks in Hawaii (where there are no large seasonal temperature changes) also make extensive and repeated offshore looping excursions lasting several weeks and covering several hundred kilometers (Meyer et al., 2018). Questions arise as to what are the drivers of these excursions or migrations and what (if anything) the animals are eating midocean? Trophic position varies with location and oceanographic environment and as sharks move between habitats - including nearshore and pelagic realms (Carlisle et al., 2012, 2015; Ferreira et al., 2017) but what they are actually eating in mid-ocean remains largely unknown. It is possible that rafting seabirds are an important component. Other partial migrations may exist within tiger shark populations and may be related to ontogeny or nutritional status although there are no empirical data to support this hypothesis (Gallagher et al., 2017).

\section{Future Research}

In concept, sharks equipped with satellite-linked tags to detect feeding events (Meyer and Holland, 2012) would reveal the 
depth and frequency of offshore feeding events. Animal-borne cameras would further elucidate the behavior. However, the problem comes with catching and identifying which sharks will undertake an offshore excursion after being tagged. Continued, long duration satellite telemetry in different regions will give further insight into temporal stability (or not) of feeding ecology. Identification of isotope or fatty acid signatures specific to seabirds (e.g., Cucherousset et al., 2012) would be a significant advance. The influence of nutritional status on movements is difficult to elucidate because nutritional status may change after a shark is tagged.

\section{Topic: Feeding Ecology and Ecologic Services}

Multiple diet studies of adult tiger sharks demonstrate them to be adaptable generalists that exploit a wide variety of prey which can vary both regionally and temporally (Lowe et al., 1996; Simpfendorfer et al., 2001; Dicken et al., 2017; inter alia). Recent stable isotope studies (Hussey et al., 2015b; Ferreira et al., 2017) confirm tiger sharks as apex predators but also that they are regionally and temporally adaptable and may function more as mesopredators in certain habitats (i.e., feeding on lower trophic level reef fishes, Ferreira et al., 2017). Additionally, there are observations of tiger sharks acting as facultative scavengers feeding at "bonanza" events such as whale carcasses (Dudley et al., 2000; Clua et al., 2013) and also examples of individuals that apparently target specific prey such as fledgling albatross (Lowe et al., 2006) and nesting sea turtles (Fitzpatrick et al., 2012). Thus, there are several aspects of feeding ecology that remain unknown including questions about the degree of individual feeding specialization (or generalization; Matich et al., 2011) and how these originate (e.g., through experience during ontogeny). Are the various types of feeding strategy related to geographic location and do these lead to the disparate growth rates (Branstetter et al., 1987; Meyer et al., 2014) that have been documented from different regions?

Neither the daily ration nor energetic requirements of adult tiger sharks have been directly measured (Hammerschlag et al., 2013) so their impact on the supporting ecosystem is not well defined. In addition to direct predation, what is the role of tiger sharks in shaping an "ecology of fear" that influences the behavior of other species (e.g., Heithaus and Dill, 2002; Heithaus, 2005; Wirsing et al., 2007; inter alia) and how does this relate to individual hunting strategies (Towner et al., 2016)?

\section{Future Research}

Meta-analysis of existing diet studies should be conducted to look at regional structure in feeding ecology and there needs to be a broader geographic scope of diet studies, especially from open ocean areas. Extensive use of feeding tags, accelerometers and cameras, especially with longer deployment periods, would capture the daily feeding and energetic intake of these animals and provide insight into the direct and indirect effects they have on disparate habitats. Overcoming the logistical constraints of using swim-tunnel respirometry to measure metabolic rates of large sharks (Payne et al., 2015) would allow empirical measurements of the energy requirements of adult tiger sharks.

\section{Topic: Social Interactions of Adults}

Virtually nothing is known regarding the social interactions of adult tiger sharks even though it is known that there can be multiple individuals using the same geographic habitat (Hammerschlag et al., 2017; Meyer et al., 2018). What is the nature and frequency of intra-specific interactions? Is there any evidence of schooling? Do tiger sharks travel together or with other species?

\section{Future Research}

Deploying "business card tags" (Holland et al., 2009) on multiple sharks caught in well-defined areas could answer questions regarding the frequency and duration of intra-specific interactions - especially if tags were developed to download archived interaction data to moored receivers. Analyzing these data using network analysis techniques would undoubtedly be productive (Stehfest et al., 2013). Deployment of shark-borne cameras would also be informative.

\section{Topic: Extent of Lateral and Vertical Range and Impacts of Climate Change}

Several studies demonstrate linkage between tiger shark distribution and water temperature (Heithaus, 2001; Papastamatiou et al., 2013; Lea et al., 2015, 2018; Payne et al., 2018; inter alia). Tiger sharks occupy a broad thermal niche with a preference for temperatures between $\sim 17^{\circ} \mathrm{C}$ and $\sim 28^{\circ} \mathrm{C}$ (Payne et al., 2018) and migrate in response to changing SSTs. However, the impacts of El Niño Southern Oscillation (ENSO) events are unknown. Overall tiger sharks may be climate change "winners"; they eat a wide variety of prey and are thus protected against climate-change driven demise of any one prey type. Warming SSTs may also extend their range toward the poles (Last et al., 2010; Payne et al., 2018).

\section{Future Research}

Electronic tagging studies - both acoustic and satellite-linked have revealed distributions and aspects of habitat use for multiple species that are not obvious through catch statistics or mark/recapture studies (see Hussey et al., 2015a). The extent of current range and any future changes in distribution may be detectable through the use of long-term acoustic transmitters and the establishment of collaborative acoustic arrays throughout the coastal margins of regions such as North America (Animal Telemetry Network; Block et al., 2016) and Australia (Integrated Marine Observing System Animal Tracking Facility; Hoenner et al., 2018) where they have access to a range of temperatures. The deployment of "oceanography" tags that can document in situ temperature, salinity and oxygen levels experienced by the sharks will help to define current physiological tolerance and habitat preferences and inform models of the impacts of climate change. Such data could be used to site future refugia. Satellite tagging of tiger sharks in the eastern Tropical Pacific where ENSO events are most extreme could shed light on their latitudinal 
range expansion along continental coasts with warming SSTs. A global review of historical and recent catch statistics might detect expansion of range (e.g., Last et al., 2010) and possible abandonment of areas that have become unsuitable (i.e., too hot; Payne et al., 2018).

\section{INTERACTIONS WITH HUMANS}

\section{Topic: Ecotourism}

Tiger sharks are components of ecotourism activities in multiple locations including Bahamas (Hammerschlag et al., 2012), Fiji (Brunnschweiler et al., 2014), South Africa (Dicken and Hosking, 2009), and Hawaii (Meyer et al., 2009) and shark tourism operations are increasing world-wide. In contrast to significant impacts of shark tourism on white shark (Carcharadon carcharias) biology (Huveneers et al., 2018), two studies suggest a limited effect of shark-related ecotourism on tiger sharks (Hammerschlag et al., 2012, 2017). However, these were "indirect" measurements and from a single location. Thus, there is debate as to whether "provisioning" (i.e., chumming) exacerbates the influence (if any) of ecotourism activities on the biology of sharks associated with them.

\section{Future Research}

Because the extent of provisioning varies from operation to operation and because they are sited in different environments, impact studies should be conducted on a case-by-case basis. Electronic tagging activities targeting sharks caught at ecotourism sites (e.g., Meyer et al., 2009) would elucidate impacts on their biology. Deploying tags that identify and quantify feeding events (Meyer and Holland, 2012) would be especially useful in assessing the impact of provisioning on the feeding ecology of sharks associated with ecotourism sites.

\section{Topic: Shark Behavior and Public Safety}

Worldwide, tiger sharks are the second-most likely to be involved in attacks on humans (13\%; International Shark Attack File ${ }^{2}$ ) and, in some regions such as Hawaii (Division of Aquatic Resources, Hawaii Department of Land and Natural Resources ${ }^{3}$ ), their impact is considerably greater. Given their generalist diet and the fact that tiger sharks are frequently close to humans it

\footnotetext{
${ }^{2}$ http://www.floridamuseum.ufl.edu/shark-attacks/

${ }^{3}$ http://dlnr.hawaii.gov/sharks/shark-incidents/incidents-list/
}

\section{REFERENCES}

Abraham, J. P., Baringer, M., Bindoff, N. L., Boyer, T., Cheng, L. J., Church, J. A., et al. (2013). A review of global ocean temperature observations: implications for ocean heat content estimates and climate change. Rev. Geophys. 51, 450-483. doi: $10.1002 / \mathrm{rog} .20022$

Alves, M. I. M. (1977). Algumas considerações sobre a reprodução do cação jaguara, Galeocerdo cuvieri (Le Sueur, 1822) (Selachii: Carcharhinidae). Arquivos de Ciências do Mar 17, 121-125.

Bangley, C. W., Rulifson, R. A., and Overton, A. S. (2013). Evaluating the efficiency of flushed stomach-tube lavage for collecting stomach contents from dogfish sharks. Southeast. Nat. 12, 523-533. doi: 10.1656/058.012. 0305 seems surprising that they do not bite humans more frequently. It is possible that there are fine scale (10 or 100 of meters) aspects of tiger shark behavior that reduce their interactions with recreational ocean users. Is there a "no-go" environment (e.g., depth or wave energy) that protects humans most of the time? These fine scale aspects of shark movement should be investigated.

\section{Future Research}

Active acoustic tracking of adult tiger sharks (Holland et al., 1999) in areas of high human-use would reveal fine-scale aspects of behavior that are not currently known. Double tagging focal animals with long-term transmitters detectable by acoustic receiver arrays would allow merging of fine-scale movement data with long-term habitat use data.

\section{Topic: Sharks as Oceanographers}

The use of animal-borne sensors is an emergent field in surveying the physical structure of the world's oceans (e.g., Roquet et al., 2014) and is especially pertinent given the unprecedented rates of change and need for increased monitoring (Abraham et al., 2013). The wide-ranging movements of tiger sharks (both laterally and vertically), their use of both coastal and offshore environments and their ability to tolerate capture and tagging (Gallagher et al., 2014) make them ideal candidates for the role of "sharks as oceanographers". In "proof of concept" experiments, tiger sharks equipped with "oceanography tags" are currently providing near-real time ocean profiles (pers. obs.).

\section{Future Research}

Long-term programs that release tiger sharks equipped with "oceanography tags" in various regions could make a significant contribution to our understanding of the physical structure of the world's tropical and semi-tropical oceans, coastal shelves and marginal seas while simultaneously revealing the habitat preferences of this important and iconic species.

\section{AUTHOR CONTRIBUTIONS}

All authors listed have made a substantial, direct and intellectual contribution to the work, and approved it for publication.

Beerkircher, L. R., Cortes, E., and Shivji, M. (2002). Characteristics of shark bycatch observed on pelagic longlines off the southeastern United States, 1992-2000. Mar. Fish. Rev. 64, 40-49.

Bernard, A. M., Feldheim, K. A., Heithaus, M. R., Wintner, S. P., Wetherbee, B. M., and Shivji, M. S. (2016). Global population genetic dynamics of a highly migratory, apex predator shark. Mol. Ecol. 25, 5312-5329. doi: 10.1111/mec. 13845

Block, B. A., Holbrook, C. M., Simmons, S. E., Holland, K. N., Ault, J. S., Costa, D. P., et al. (2016). Toward a national animal telemetry network for aquatic observations in the United States. Animal Biotelem. 4:6. doi: 10.1186/s40317015-0092-1

Branstetter, S. T., Musick, J. A., and Colvocoresses, J. A. (1987). A comparison of the age and growth of the tiger shark, Galeocerdo cuvieri, from 
off virginia and from the northwestern gulf of Mexico. Fish. Bull. 85, 269-279.

Brunnschweiler, J. M., Abrantes, K. G., and Barnett, A. (2014). Long-term changes in species composition and relative abundances of sharks at a provisioning site. PLoS One 9:e86682. doi: 10.1371/journal.pone.0086682

Carlisle, A. B., Goldman, K. J., Litvin, S. Y., Madigan, D. J., Bigman, J. S., Swithenbank, A. M., et al. (2015). Stable isotope analysis of vertebrae reveals ontogenetic changes in habitat in an endothermic pelagic shark. Proc. Biol. Sci. 282:20141446

Carlisle, A. B., Kim, S. L., Semmens, B. X., Madigan, D. J., Jorgensen, S. J., Perle, C. R., et al. (2012). Using stable isotope analysis to understand the migration and trophic ecology of northeastern Pacific white sharks (Carcharodon carcharias). PLoS One 7:e30492. doi: 10.1371/journal.pone.0030492

Castro, J. I. (2009). Observations on the reproductive cycles of some viviparous North American sharks. Aqua 15, 205-222.

Clua, E., Chauvet, C., Read, T., Werry, J. M., and Lee, S. Y. (2013). Behavioural patterns of a tiger shark (Galeocerdo cuvier) feeding aggregation at a blue whale carcass in prony bay. New caledonia. Mar. Freshw. Behav. Physiol. 46, 1-20. doi: 10.1080/10236244.2013.773127

Compagno, L. J. V. (1984). FAO species catalogue. Volume 4. Sharks of the world. An annotated and illustrated catalogue of shark species known to date. Part 2. Carcharhiniformes. FAO Fish. Synop. No. 125 4(Pt 2), 251-655.

Cucherousset, J., Boulêtreau, S., Azémar, F., Compin, A., Guillaume, M., and Santoul, F. (2012). "Freshwater Killer Whales": beaching behavior of an alien fish to hunt land birds. PLoS One 7:e50840. doi: 10.1371/journal.pone. 0050840

Daly-Engel, T. S., Grubbs, R. D., Holland, K. N., Toonen, R. J., and Bowen, B. W. (2006). Assessment of multiple paternity in single litters from three species of carcharhinid sharks in hawaii. Environ. Biol. Fish. 76, 419-424. doi: 10.1007/ s10641-006-9008-5

Dicken, M. L., and Hosking, S. G. (2009). Socio-economic aspects of the tiger shark diving industry within the aliwal shoal marine protected area, South africa. Afr. J. Mar. Sci. 31, 227-232. doi: 10.2989/AJMS.2009.31.2.10.882

Dicken, M. L., Hussey, N. E., Christiansen, H. M., Smale, M. J., Nkabi, N., Cliff, G., et al. (2017). Diet and trophic ecology of the tiger shark (Galeocerdo cuvier) from South african waters. PLoS One 12:e0177897. doi: 10.1371/journal.pone. 0177897

Domingo, A., Coelho, R., Cortes, E., Garcia-Cortes, B., Mas, F., Mejuto, J., et al. (2016). Is the tiger shark Galeocerdo cuvier a coastal species? Expanding its distribution range in the atlantic ocean using at-sea observer data. J. Fish Biol. 88, 1223-1228. doi: 10.1111/jfb.12887

Driggers, W. B., Ingram, G. W., Grace, M. A., Gledhill, C. T., Henwood, T. A., Horton, C. N., et al. (2008). Pupping areas and mortality rates of young tiger sharks Galeocerdo cuvier in the western North atlantic ocean. Aquat. Biol. 2, 161-170. doi: 10.3354/ab00045

Dudley, S. F., Anderson-Reade, M. D., Thompson, G. S., and McMullen, P. B. (2000). Concurrent scavenging off a whale carcass by great white sharks, Carcharodon carcharias, and tiger sharks, Galeocerdo cuvier. Fish. Bull. 98, 646-649.

Ferreira, L. C., Thums, M., Heithaus, M. R., Barnett, A., Abrantes, K. G., Holmes, B. J., et al. (2017). The trophic role of a large marine predator, the tiger shark Galeocerdo cuvier. Sci. Rep. 7:7641. doi: 10.1038/s41598-01707751-2

Fitzpatrick, R., Thums, M., Bell, I., Meekan, M. G., Stevens, J. D., and Barnett, A. (2012). A comparison of the seasonal movements of tiger sharks and green turtles provides insight into their predator-prey relationship. PLoS One 7:e51927. doi: 10.1371/journal.pone.0051927

Gallagher, A. J., Serafy, J. E., Cooke, S. J., and Hammerschlag, N. (2014). Physiological stress response, reflex impairment, and survival of five sympatric shark species following experimental capture and release. Mar. Ecol. Prog. Ser. 496, 207-218. doi: 10.3354/meps 10490

Gallagher, A. J., Skubel, R. A., Pethybridge, H. R., and Hammerschlag, N. (2017). Energy metabolism in mobile, wild-sampled sharks inferred by plasma lipids. Conserv. physiol. 5:cox002. doi: 10.1093/conphys/cox002

Hammerschlag, N., Gallagher, A. J., and Carlson, J. K. (2013). A revised estimate of daily ration in the tiger shark with implication for assessing ecosystem impacts of apex predators. Funct. Ecol. 27, 1273-1274. doi: 10.1111/1365-2435.12157
Hammerschlag, N., Gallagher, A. J., Wester, J., Luo, J., and Ault, J. S. (2012). Don’t bite the hand that feeds: assessing ecological impacts of provisioning ecotourism on an apex marine predator. Funct. Ecol. 26, 567-576. doi: 10.1111/j.1365-2435. 2012.01973.x

Hammerschlag, N., Gutowsky, L. F. G., Gallagher, A. J., Matich, P., and Cooke, S. J. (2017). Diel habitat use patterns of a marine apex predator (tiger shark, Galeocerdo cuvier) at a high use area exposed to dive tourism. J. Exp. Mar. Biol. Ecol. 495, 24-34. doi: 10.1016/j.jembe.2017.05.010

Heithaus, M. R. (2001). The biology of tiger sharks, Galeocerdo cuvier, in shark bay, western australia: sex ratio, size distribution, diet, and seasonal changes in catch rates. Environ. Biol. Fish. 61, 25-36. doi: 10.1023/A:1011021210685

Heithaus, M. R. (2005). Habitat use and group size of pied cormorants (Phalacrocorax varius) in a seagrass ecosystem: possible effects of food abundance and predation risk. Mar. Biol. 147, 27-35. doi: 10.1007/s00227-0041534-0

Heithaus, M. R., and Dill, L. M. (2002). Food availability and tiger shark predation risk influence bottlenose dolphin habitat use. Ecology 83, 480-491. doi: 10.1890/ 0012-9658(2002)083[0480:FAATSP]2.0.CO;2

Heupel, M. R., Carlson, J. K., and Simpfendorfer, C. A. (2007). Shark nursery areas: concepts, definition, characterization and assumptions. Mar. Ecol. Prog. Ser. 337, 287-297. doi: 10.3354/meps337287

Heupel, M. R., and Hueter, R. E. (2001). "Use of an automated acoustic telemetry system to passively track juvenile blacktip shark movements," in Electronic Tagging and Tracking in Marine Fisheries, eds J. R. Sibert and J. L. Nielsen (Dordrecht: Springer), 217-236.

Hoenner, X., Huveneers, C., Steckenreuter, A., Simpfendorfer, C., Tattersall, K., Jaine, F., et al. (2018). Australia's continental-scale acoustic tracking database and its automated quality control process. Sci. Data 5:170206. doi: 10.1038/ sdata.2017.206

Holland, K. N., Meyer, C. G., and Dagorn, L. C. (2009). Inter-animal telemetry: results from first deployment of acoustic 'business card'tags. Endanger. Species Res. 10, 287-293. doi: 10.3354/esr00226

Holland, K. N., Wetherbee, B. M., Lowe, C. G., and Meyer, C. G. (1999). Movements of tiger sharks (Galeocerdo cuvier) in coastal hawaiian waters. Mar. Biol. 134, 665-673. doi: 10.1038/s41598-018-23006-0

Holland, K. N., Wetherbee, B. M., Peterson, J. D., and Lowe, C. G. (1993). Movements and distribution of hammerhead shark pups on their natal grounds. Copeia 1993, 495-502. doi: 10.2307/1447150

Holmes, B. J. (2015). The Biology and Ecology of the Tiger Shark (Galeocerdo cuvier) on the East Coast of Australia. Ph.D. Thesis, The University of Queensland, St Lucia, Brisbane, Australia.

Holmes, B. J., Pepperell, J. G., Griffiths, S. P., Jaine, F. R., Tibbetts, I. R., and Bennett, M. B. (2014). Tiger shark (Galeocerdo cuvier) movement patterns and habitat use determined by satellite tagging in eastern Australian waters. Mar. Biol. 161, 2645-2658. doi: 10.1007/s00227-014-2536-1

Holmes, B. J., Pope, L. C., Williams, S. M., Tibbetts, I. R., Bennett, M. B., and Ovenden, J. R. (2018). Lack of multiple paternity in the oceanodromous tiger shark (Galeocerdo cuvier). R. Soc. Open Sci. 5:171385. doi: 10.1098/rsos.171385

Holmes, B. J., Sumpton, W. D., Mayer, D. G., Tibbetts, I. R., Neil, D. T., and Bennett, M. B. (2012). Declining trends in annual catch rates of the tiger shark (Galeocerdo cuvier) in queensland, Australia. Fish. Res. 12, 38-45. doi: 10.1016/j.fishres.2012.06.005

Holmes, B. J., Williams, S. M., Otway, N. M., Nielsen, E. E., Maher, S. L., Bennett, M. B., et al. (2017). Population structure and connectivity of tiger sharks (Galeocerdo cuvier) across the Indo-pacific ocean basin. R. Soc. Open Sci. 4:170309. doi: 10.1098/rsos. 170309

Hussey, N. E., Kessel, S. T., Aarestrup, K., Cooke, S. J., Cowley, P. D., Fisk, A. T., et al. (2015a). Aquatic animal telemetry: a panoramic window into the underwater world. Science 348:1255642. doi: 10.1126/science. 1255642

Hussey, N. E., MacNeil, M. A., Siple, M. C., Popp, B. N., Dudley, S. F., and Fisk, A. T. (2015b). Expanded trophic complexity among large sharks. Food Webs 4, 1-7. doi: 10.1016/j.fooweb.2015.04.002

Huveneers, C., Watanabe, Y. Y., Payne, N. L., and Semmens, J. M. (2018). Interacting with wildlife tourism increases activity of white sharks. Conserv. physiol. 6, coy019. doi: 10.1093/conphys/coy019

Kinney, M. J., Hussey, N. E., Fisk, A. T., Tobin, A. J., and Simpfendorfer, C. A. (2011). Communal or competitive? Stable isotope analysis provides evidence of 
resource partitioning within a communal shark nursery. Mar. Ecol. Prog. Ser. 439, 263-276. doi: 10.3354/meps09327

Last, P., White, W., Gledhill, D., Hobday, A., Brown, R., Edgar, G., et al. (2010). Long-term shifts in abundance and distribution of a temperature fish fauna: a response to climate change and fishing practices. Glob. Ecol. Biogeogr. 20, 58-72. doi: 10.1111/j.1466-8238.2010.00575.x

Lea, J. S., Wetherbee, B. M., Queiroz, N., Burnie, N., Aming, C., Sousa, L. L., et al. (2015). Repeated, long-distance migrations by a philopatric predator targeting highly contrasting ecosystems. Sci. Rep. 5:11202. doi: 10.1038/srep11202

Lea, J. S., Wetherbee, B. M., Sousa, L. L., Aming, C., Burnie, N., Humphries, N. E., et al. (2018). Ontogenetic partial migration is associated with environmental drivers and influences fisheries interactions in a marine predator. ICES J. Mar. Sci. 75, 1383-1392. doi: 10.1093/icesjms/fsx238

Lowe, C. G. (2002). Bioenergetics of free-ranging juvenile scalloped hammerhead sharks (Sphyrna lewini) in Kâne’ohe bay, Ö’ahu, HI. J. Exp. Mar. Biol. Ecol. 278, 141-156. doi: 10.1016/S0022-0981(02)00331-3

Lowe, C. G., Wetherbee, B. M., Crow, G. L., and Tester, A. L. (1996). Ontogenetic dietary shifts and feeding behavior of the tiger shark, Galeocerdo cuvier, in Hawaiian waters. Environ. Biol. Fish. 47, 203-211. doi: 10.1007/BF00005044

Lowe, C. G., Wetherbee, B. M., and Meyer, C. G. (2006). Using acoustic telemetry monitoring techniques to quantify movement patterns and site fidelity of sharks and giant trevally around french frigate shoals and midway atoll. Atoll Res. Bull. 543, 281-303.

Matich, P., Heithaus, M. R., and Layman, C. A. (2011). Contrasting patterns of individual specialization and trophic coupling in two marine apex predators. J. Animal Ecol. 80, 294-305. doi: 10.1111/j.1365-2656.2010.01753.x

Meyer, C. G., Anderson, J. M., Coffey, D. M., Hutchinson, M. R., Royer, M. A., and Holland, K. N. (2018). Habitat geography around Hawaii's oceanic islands influences tiger shark (Galeocerdo cuvier) spatial behaviour and shark bite risk at ocean recreation sites. Sci. Rep. 8:4945. doi: 10.1038/s41598-018-23006-0

Meyer, C. G., Dale, J. J., Papastamatiou, Y. P., Whitney, N. M., and Holland, K. N. (2009). Seasonal cycles and long term trends in abundance and species composition of sharks associated with cage diving ecotourism activities in Hawaii. Environ. Conserv. 36, 104-111. doi: 10.1017/S0376892909990038

Meyer, C. G., and Holland, K. N. (2012). Autonomous measurement of ingestion and digestion processes in free-swimming sharks. J. Exp. Biol. 215, 3681-3684. doi: $10.1242 /$ jeb. 075432

Meyer, C. G., O’Malley, J. M., Papastamatiou, Y. P., Dale, J. J., Hutchinson, M. R., Anderson, J. M., et al. (2014). Growth and maximum size of tiger sharks (Galeocerdo cuvier) in Hawaii. PLoS One 9:e84799. doi: 10.1371/journal.pone. 0084799

Papastamatiou, Y. P., Itano, D. G., Dale, J. J., Meyer, C. G., and Holland, K. N. (2010). Site fidelity and movements of sharks associated with ocean-farming cages in hawaii. Mar. Freshw. Res. 61, 1366-1375. doi: 10.1071/MF10056

Papastamatiou, Y. P., Meyer, C. G., Carvalho, F., Dale, J. J., Hutchinson, M. R. and Holland, K. N. (2013). Telemetry and random walk models reveal complex patterns of partial migration in a large marine predator. Ecology 94, 2595-2606. doi: 10.1890/12-2014.1

Payne, N. L., Meyer, C. G., Smith, J. A., Houghton, J. D., Barnett, A., Holmes, B. J., et al. (2018). Combining abundance and performance data reveals how temperature regulates coastal occurrences and activity of a roaming apex predator. Glob. Chang. Biol. 24, 1884-1893. doi: 10.1111/gcb.14088

Payne, N. L., Snelling, E. P., Fitzpatrick, R., Seymour, J., Courtney, R., Barnett, A., et al. (2015). A new method for resolving uncertainty of energy requirements in large water breathers: the 'mega-flume'seagoing swim-tunnel respirometer. Methods Ecol. Evol. 6, 668-677. doi: 10.1111/2041-210X.12358

Polovina, J. J., and Lau, B. B. (1993). Temporal and spatial distribution of catches of tiger sharks, Galeocerdo cuvier, in the pelagic longline fishery around the Hawaiian Islands. Mar. Fish. Rev. 55, 1-3.
Rivera-López, J. (1970). Studies on the Biology of the Nurse Shark, Ginglymostoma Cirratum Bonnaterre, and the Tiger Shark, Galeocerdo Cuvieri Péron and Le Sueur. MS Thesis. University of Puerto Rico, Mayaguez, Puerto Rico.

Roquet, F., Williams, G., Hindell, M. A., Harcourt, R., McMahon, C., Guinet, C., et al. (2014). A Southern Indian ocean database of hydrographic profiles obtained with instrumented elephant seals. Sci. Data 1:140028. doi: 10.1038/ sdata.2014.28

Simpfendorfer, C. (1992). Biology of tiger sharks (Galeocerdo cuvier) caught by the queensland shark meshing program off townsville, Australia. Mar. Freshw. Res. 43, 33-43. doi: 10.1071/MF9920033

Simpfendorfer, C. A., Goodreid, A. B., and McAuley, R. B. (2001). Size, sex and geographic variation in the diet of the tiger shark, Galeocerdo cuvier, from Western Australian waters. Environ. Biol. Fish. 61, 37-46. doi: 10.1023/A: 1011021710183

Skinner, J. P., Mitani, Y., Burkanov, V. N., and Andrews, R. D. (2014). Proxies of food intake and energy expenditure for estimating the time-energy budgets of lactating northern fur seals Callorhinus ursinus. J. Exp. Mar. Biol. Ecol. 461, 107-115. doi: 10.1016/j.jembe.2014.08.002

Springer, S. (1967). "Social organization of shark populations," in Sharks, Skates and Rays, eds P. W. Gilbert, R. W. Mathewson, and D. P. Rall (Baltimore, MD: John Hopkins Press), 149-174.

Stehfest, K. M., Patterson, T. A., Dagorn, L., Holland, K. N., Itano, D., and Semmens, J. M. (2013). Network 524 analysis of acoustic tracking data reveals the structure and stability of fish aggregations in the ocean. Animal Behav. 85, 839-848. doi: 10.1016/j.anbehav.2013.02.003

Sulikowski, J. A., Wheeler, C. R., Gallagher, A. J., Prohaska, B. K., Langan, J. A., and Hammerschlag, N. (2016). Seasonal and life-stage variation in the reproductive ecology of a marine apex predator, the tiger shark Galeocerdo cuvier, at a protected female-dominated site. Aquat. Biol. 24, 175-184. doi: $10.3354 / \mathrm{ab} 00648$

Towner, A. V., Leos-Barajas, V., Langrock, R., Schick, R. S., Smale, M. J., Kaschke, T., et al. (2016). Sex-specific and individual preferences for hunting strategies in white sharks. Funct. Ecol. 30, 1397-1407. doi: 10.1111/1365-2435. 12613

Werry, J. M., Planes, S., Berumen, M. L., Lee, K. A., Braun, C. D., and Clua, E. (2014). Reef-fidelity and migration of tiger sharks, Galeocerdo cuvier, across the coral sea. PLoS One 9:e83249. doi: 10.1371/journal.pone.0083249

Whitney, N. M., and Crow, G. L. (2007). Reproductive biology of the tiger shark (Galeocerdo cuvier) in Hawaii. Mar. Biol. 151, 63-70. doi: 10.1007/s00227-0060476-0

Wintner, S. P., and Dudley, S. F. (2000). Age and growth estimates for the tiger shark, Galeocerdo cuvier, from the east coast of South Africa. Mar. Freshw. Res. 51, 43-53. doi: 10.1071/MF99077

Wirsing, A. J., Heithaus, M. R., and Dill, L. M. (2007). Fear factor: do dugongs (Dugong dugon) trade food for safety from tiger sharks (Galeocerdo cuvier)? Oecologia 153, 1031-1040.

Conflict of Interest Statement: The authors declare that the research was conducted in the absence of any commercial or financial relationships that could be construed as a potential conflict of interest.

Copyright (C) 2019 Holland, Anderson, Coffey, Holmes, Meyer and Royer. This is an open-access article distributed under the terms of the Creative Commons Attribution License (CC BY). The use, distribution or reproduction in other forums is permitted, provided the original author(s) and the copyright owner(s) are credited and that the original publication in this journal is cited, in accordance with accepted academic practice. No use, distribution or reproduction is permitted which does not comply with these terms. 